\title{
Effects of oregano essential oil and capsicum extract on fattening, serum constituents, and rumen fermentation of lambs
}

\author{
H.B. Ünlü ${ }^{1}$, H.H. İpçak ${ }^{2}$, Ç. Kandemir ${ }^{1}$, M. Özdoğan ${ }^{3 \#}$ \& Ö. Canbolat ${ }^{4}$, \\ ${ }^{1}$ Department of Animal Science, Faculty of Agriculture, Ege University, İzmir, Turkey \\ ${ }^{2}$ Dicle University, Agriculture Faculty, Department of Animal Science, 21280, Diyarbekir, Turkey \\ ${ }^{3}$ Adnan Menderes University, Agriculture Faculty, Department of Animal Science, 09010, Aydin, Turkey \\ ${ }^{4}$ Uludağ University, Agriculture Faculty, Department of Animal Science, 16059, Bursa, Turkey
}

(Received 22 November 2020; Accepted 31 December 2020; Published 25 February 2021)

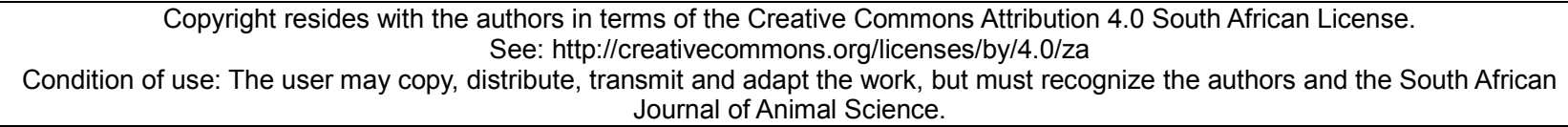

\begin{abstract}
This study investigated dietary supplementation of weaned lambs with Origanum vulgare essential oil and Capsicum oleoresin (chilli pepper) extract. Thirty-six eight-week-old male and female Menemen lambs were used in this study. Three dietary treatment groups consisted of T1, an unsupplemented control group; T2, a group supplemented with $300 \mathrm{mg} / \mathrm{kg}$ oregano essential oil, and T3, a group supplemented with 300 $\mathrm{mg} / \mathrm{kg}$ Capsicum oleoresin. Feed and fresh water were available to the lambs ad libitum during the 56-day experiment. No significant effects of treatment were detected on growth rate, feed intake and feed conversion. In addition, serum urea, creatine, total protein, albumin, amylase, aspartate amino transferase (AST), alanine amino transferase (ALT), and gamma glutamyl transferase (GGT) levels did not differ among treatments on day 56 of the study. When oregano oil and capsicum extract were added to the feed, total volatile fatty acids (TVFA), acetate (AA), propionate (PA), butyrate (BA), isobutyrate (IBA), valerate (VA), and $A A$ to $P A$ ratio in the rumen were decreased significantly in comparison with the control group at two hours after feeding, with the effect of T2 being greater than that of T3. Female lambs had lower levels of TVFA than male lambs. Thus, although neither additive affected fattening performance and serum constituents of the lambs, both altered the rumen fatty acid profile.
\end{abstract}

Keywords: capsicum, lamb, oregano oil, performance, rumen parameters

\#Corresponding author: ozdoganmursel@gmail.com

\section{Introduction}

High concentrate diets are generally used in intensive systems of fattening ruminant livestock. Within this framework, natural feed additives are crucial to maintaining animal health. The antagonistic interactions of amino acids and hexoses in the rumen pose threats to the health of animals (Busquet et al., 2006; Calsamiglia et al., 2007). The use of various feed additives has proved to improve efficiency, and decrease the production of methane and ammonia nitrogen through manipulation of the rumen microbiome (McGuffey et al., 2001). These additives include milled aromatic plants and their extracts. They have been reported to have physiological consequences for certain serum constituents, pancreatic hormones, digestive enzymes and rumen microflora (Babu \& Srinivasan, 1997; Chaiyasit et al., 2009; Oh et al., 2017; Seirafy \& Sobhanirad, 2017).

In vitro studies have shown that aromatic vegetable oils have antimicrobial and antibacterial effects (Adaszek et al., 2019; Maksimova et al., 2014; Burt, 2004), particularly oregano and chilli pepper extract. Whereas oregano oil is a phenolic compound (Veldhuizen et al., 2006), capsaicinoids (especially capsaicin, dihydrocapsaicin, nordihydrocapsaicin, homodihydrocapsaicin and homocapsaicin) are the main constituents of chilli pepper extract (Reyes-Escogido et al., 2011; Koffi-Nevry et al., 2012). In concentrate-based feeding programmes, chilli pepper extract has been shown to be effective in regulating rumen $\mathrm{pH}$ (Cardozo et al., 2005; Rodríguez-Prado et al., 2012). In vivo studies found that oregano and chilli pepper oils increase the performance and quality of animal products (Cardozo et al., 2006; Sanati et al., 2018). In addition, oregano and chilli pepper extracts and their secondary metabolites might act as modifiers of rumen fermentation in 
beef production systems (Cardozo et al., 2005; Cardozo et al., 2006; Castillejos et al., 2006; Calsamiglia et al., 2007; Foskolos et al., 2020). However, these additives have rarely been shown to modify serum constituents. It was thought that there was a need to evaluate further the consequences of using dietary oregano oil and chilli pepper extract on the performance, serum constituents and rumen fermentation parameters of fattening lambs.

\section{Materials and Methods}

This study was approved by Ege University Animal Care and Use Committee No. 2014-091. A total of 36 Menemen (lle de France x Kivircik) male and female lambs, aged eight weeks, were used for the study. At the beginning of the experiment, the mean bodyweights (BWs) of male and female lambs for the three treatments were $19.15 \pm 0.79$ and $19.21 \pm 0.79 \mathrm{~kg}$, respectively. After being weighed, the animals were stratified by live weight and randomly allocated to T1, an unsupplemented control group, T2, a group supplemented with $300 \mathrm{mg} / \mathrm{kg}$ oregano essential oil, and T3, a group supplemented with $300 \mathrm{mg} / \mathrm{kg}$ chilli pepper extract. A total of 12 lambs (six males and six females) were assigned to each group. They were housed in individual pens $\left(2 \mathrm{~m}^{2} / \mathrm{lamb}\right)$ for the duration of the experiment.

Oregano essential oil was obtained by steam distillation from selected Oregano onites ssp. growing wild in Turkey. The carvacrol and thymol contents, which are the most active compounds of oregano essential oil, were $85.87 \%$ and $7.81 \%$, respectively. Chilli pepper extract, which contains $99 \%$ Capsicum oleoresin, was obtained by steam distillation from selected Capsicum annuum L. The basal diet met the nutrient requirements (NRC, 1985) of animals for roughage and concentrate feed (Table 1). The diets and drinking water were offered ad libitum. The study was conducted over a feeding period of 56 days. Live weights (LW) and dry matter intake (DMI) were recorded at 14-day intervals, and daily weight gain (DWG) and FCR were calculated. The lambs were slaughtered at a commercial slaughterhouse at the end of the experiment.

Table 1 Formulations for diets containing supplemental oregano essential oil and Capsicum oleoresin extract to feed fattening lambs

\begin{tabular}{lrrr}
\hline & \multicolumn{3}{c}{ Dietary treatments $^{1}$} \\
\cline { 2 - 4 } Ingredients, g/kg & Control & Oregano & Capsicum \\
\hline Alfalfa pellets & 103.1 & 103.1 & 103.1 \\
Barley & 257.7 & 257.7 & 257.7 \\
Soybean hulls & 124.1 & 124.1 & 124.1 \\
Wheat bran & 113.5 & 113.5 & 113.5 \\
Corn grain & 103.1 & 103.1 & 103.1 \\
Wheat & 103.1 & 103.1 & 103.1 \\
Soybean meal & 102.5 & 102.5 & 102.5 \\
Cotton meal & 51.9 & 51.9 & 51.9 \\
Soybean oil & 5.2 & 5.2 & 5.2 \\
Limestone & 23.6 & 23.6 & 23.6 \\
Salt & 5.7 & 5.7 & 5.7 \\
Ammonium chloride & 5.2 & 5.2 & 5.2 \\
Vitamin mineral premix & & 1.5 & 1.5 \\
Oregano essential oil & 1.5 & 0.3 & 0.3 \\
Capsicum extract & & &
\end{tabular}

'Dry matter: 896.9, ash: 72.7, digestible crude protein: 165.0; ether extract: 27.9, crude fibre: 110.0, sugar, 43.1, starch: 275.9, neutral detergent fibre: 24.4 , acid detergent fibre: 139.0 , calcium: 12.0 , phosphorus: $4.0 \mathrm{~g} / \mathrm{kg}$; metabolizable energy: $2600 \mathrm{kcal} / \mathrm{kg}$

${ }^{2}$ Vitamin A: $11000 \mathrm{IU}$, vitamin B1: $3 \mathrm{mg}$, vitamin D3: $5000 \mathrm{iu}, 0.069 \mathrm{mg}$, vitamin B2: $8 \mathrm{mg}$, vitamin E: $150 \mathrm{mg}$, vitamin K3: $3 \mathrm{mg}$, vitamin B6: $4 \mathrm{mg}$, vitamin B12: $0.02 \mathrm{mg}$, niacin: $60 \mathrm{mg}$, d-pantothenic acid $15 \mathrm{mg}$, folic acid: $2 \mathrm{mg}$, biotin: $0.2 \mathrm{mg}$, vitamin C: $100 \mathrm{mg}$, cobalt: $400 \mathrm{mg}$, copper: $4000 \mathrm{mg}$. iodine: $500 \mathrm{mg}$, iron: $5000 \mathrm{mg}$, manganese: $500 \mathrm{mg}$, selenium: 200 $\mathrm{mg}$, zinc: $5000 \mathrm{mg}$ 
Nutrient contents of the dietary ingredients and concentrate that were fed to the lambs were analysed according to the AOAC (1997), namely dry matter (DM) (method 934.01), ash (method 942.05), crude protein (CP) (method 990.03), ether extract (EE) (method 920.39), and crude fibre (CF) (method 962.09). The sugar content of the materials was determined by the Luff-Scroll method and their starch by the polarimetric method (AOAC, 1997). Neutral detergent fibre (NDF) and acid detergent fibre (ADF) contents were determined following Van Soest et al. (1991). Phosphorus (P) contents of the materials were read by spectrophotometer (Double Beam UV-V15, Perkin Elmer, Waltham, Massachusetts, USA) by calorimetric methods. Atomic absorption spectroscopy (Ultrospec 2100 Pro UV-visible spectrophotometer, Biochrom US, Holliston, Massachusetts, USA) was used to determine calcium ( $\mathrm{Ca}$ ) concentration. Metabolizable energy (ME, kcal $/ \mathrm{kg}$ ) content of the diet was predicted in $\mathrm{kcal} / \mathrm{kg}^{-1}$ of DM from its CP, CF, and EE contents (TSI, 1991):

$$
M E=3260+0.455 x C P+3.517 x E E-4.037 x C F
$$

At the beginning and end of the experiment, $10 \mathrm{ml}$ of blood was drawn from the jugular vein of each animal at 10:00. The blood samples were brought to the laboratory at $4{ }^{\circ} \mathrm{C}$. In the laboratory, the serum was harvested and urea, creatine, protein, albumin, amylase, AST, ALT and GGT contents were measured using a filtered photometric method on the Biotecnica BT-2000 Plus device (Biotecnica Instruments, Rome, Italy).

At the end of the experiment, two hours after feeding, $50 \mathrm{ml}$ of rumen fluid was drawn from each animal with a rumen probe to measure $\mathrm{pH}$, TVFA, AA, PA BA, IBA, VA, and IVA to assess rumen fermentation. The $\mathrm{pH}$ of the rumen fluid was measured in the digital $\mathrm{pH}$ meter. Then these samples were filtered, $0.5 \mathrm{ml} 1 \mathrm{M}$ hydrochloric acid was added, and stored at $-20^{\circ} \mathrm{C}$ until the VFAs were determined (Erwin et al., 1961). For the analysis of VFA in the rumen fluid, 5-7 ml rumen fluid was centrifuged at $4{ }^{\circ} \mathrm{C}(6000$ $\mathrm{rpm}, 10$ minutes). Then $5 \mathrm{ml}$ rumen liquid was decanted into a new centrifuge tube to which $1 \mathrm{~mL}$ of metaphosphoric acid was added and held for 30 minutes. After this process, the tubes were centrifuged again (3000 rpm) and the supernatant was separated and put into Eppendorf tubes. The VFA contents of the samples were measured with a gas chromatography device (Agilent Technologies, Anaheim, California, USA). The detector temperature was programmed at $260^{\circ} \mathrm{C}$, injection temperature was $250{ }^{\circ} \mathrm{C}$, oven temperature is programmed from $45^{\circ} \mathrm{C}$ to $250^{\circ} \mathrm{C}$ with gradual $2{ }^{\circ} \mathrm{C}$ increases, and hydrogen gas transition rate was $30 \mathrm{ml} / \mathrm{min}$. Each sample was analysed twice (Erwin et al. 1961).

The data were subjected to analysis of variance using the general linear model procedure of SPSS (version 25, IBM Inc., Chicago, Illinois, USA). Effect of treatment and sex was determined from a two-way analysis of variance with interaction. Differences among treatment were determined using Duncan's multiple range test. Differences were considered significant based at the 0.05 level of probability.

\section{Results and Discussion}

The treatment by sex interaction was not significant for any of the traits $(P>0.05)$. Oregano oil and capsicum extract supplementation had no effect on final BW, DWG, DMI and FCR. However, male lambs grew faster than female lambs and were heavier at the end of the experiment $(P<0.01)$. The effects of oregano oil and capsicum extract supplementation on fattening performance, FI and FCR of lambs are given in Table 2.

The effects of oregano oil and capsicum extract supplementation on the serum constituents of the lambs are given in Table 3. Oregano oil and capsicum extract supplementation had no significant effect on the serum constituents. Nor did the interaction of treatment and sex. However, serum urea concentration was higher in female lambs than in male lambs $(P<0.05)$.

Oregano oil supplementation decreased the TVFA, AA, PA, BA, IVA, VA, and AA/PA contents of the rumen fluid and increased its $\mathrm{pH}$. Conversely, capsicum extract supplementation decreased the total VFA, $\mathrm{AA}, \mathrm{PA}$, and IBA concentrations and $\mathrm{pH}$. The treatment by sex interaction affected TVFA and PA concentrations and $\mathrm{pH}(P<0.05)$. The effects of oregano oil and capsicum extract supplementation on serum parameters of lambs are given in Table 4. 
Table 2 Effects of oregano oil and capsicum extract supplementation on fattening performance, feed intake and feed conversion ratio of lambs

\begin{tabular}{lccccc}
\hline & Initial BW, $\mathrm{kg}$ & Final BW, kg & DWG, g/d & DMl, g/d & FCR \\
\hline Treatment & & & & & \\
$\quad$ Control & 18.87 & 40.81 & 391 & 1.193 & 3.12 \\
Oregano & 18.81 & 40.64 & 390 & 1.225 & 3.15 \\
Capsicum & 18.72 & 39.58 & 373 & 1.174 & 3.15 \\
$\quad$ SE & 0.95 & 1.07 & 0.01 & 0.038 & 0.09 \\
\hline Sex & & & & & \\
$\quad$ Male & 18.92 & 42.11 & 415 & 1.210 & 2.97 \\
Female & 18.68 & 38.57 & 354 & 1.173 & 3.31 \\
SE & 0.79 & 0.88 & 0.01 & 0.028 & 0.07 \\
\hline$P$-value & & & & & \\
$\quad$ Treatment & 0.994 & 0.694 & 0.581 & 0.600 & 0.600 \\
$\quad$ Sex & 0.835 & 0.008 & 0.001 & 0.270 & 0.274 \\
$\quad$ Treatment x sex & 0.983 & 0.611 & 0.281 & 0.341 & 0.375 \\
\hline
\end{tabular}

BW: bodyweight, DWG: daily weight gain, DMI: total dry matter intake, FCR: feed conversion ratio

Table 3 Effects of oregano oil and capsicum extract supplementation on serum constituents of lambs after 56 days on feed

\begin{tabular}{|c|c|c|c|c|c|c|c|c|}
\hline & $\begin{array}{l}\text { Urea, } \\
\mathrm{mg} / \mathrm{dl}\end{array}$ & $\begin{array}{c}\text { Creatinine, } \\
\mathrm{g} / \mathrm{dl}\end{array}$ & $\begin{array}{c}\text { Total protein, } \\
\text { g/dl }\end{array}$ & $\begin{array}{l}\text { Albumin, } \\
\text { g/dl }\end{array}$ & $\begin{array}{c}\text { Amylase, } \\
\text { U/I }\end{array}$ & $\begin{array}{l}\text { AST, } \\
\text { U/I }\end{array}$ & $\begin{array}{c}\mathrm{ALT}, \\
\mathrm{U} / \mathrm{I}\end{array}$ & $\begin{array}{c}\text { GGT, } \\
\text { U/I }\end{array}$ \\
\hline \multicolumn{9}{|l|}{ Treatment } \\
\hline Control & 54.47 & 0.65 & 6.69 & 3.92 & 14.64 & 162.47 & 15.33 & 100.86 \\
\hline Oregano & 57.81 & 0.69 & 6.46 & 3.86 & 17.67 & 174.22 & 16.56 & 105.88 \\
\hline Capsicum & 56.37 & 0.69 & 6.38 & 3.84 & 14.18 & 168.49 & 14.96 & 96.83 \\
\hline SE & 3.13 & 0.37 & 0.09 & 0.04 & 1.61 & 26.23 & 0.87 & 11.29 \\
\hline \multicolumn{9}{|l|}{ Sex } \\
\hline Male & 51.45 & 0.67 & 6.51 & 3.87 & 14.54 & 164.78 & 16.65 & 107.53 \\
\hline Female & 60.99 & 0.68 & 6.51 & 3.87 & 16.45 & 172.01 & 14.58 & 94.85 \\
\hline SE & 2.55 & 0.03 & 0.07 & 0.03 & 1.31 & 21.39 & 0.71 & 9.20 \\
\hline \multicolumn{9}{|l|}{$P$-value } \\
\hline Treatment & 0.755 & 0.728 & 0.076 & 0.423 & 0.271 & 0.951 & 0.415 & 0.852 \\
\hline Sex & 0.013 & 0.774 & 0.994 & 0.985 & 0.313 & 0.813 & 0.051 & 0.338 \\
\hline Group x sex & 0.221 & 0.799 & 0.948 & 0.404 & 0.511 & 0.134 & 0.593 & 0.422 \\
\hline
\end{tabular}


Table 4 Effects of oregano oil and capsicum extract supplementation on rumen fermentation of lambs

\begin{tabular}{lccccccccc}
\hline & \multicolumn{10}{c}{ Volatile fatty acids, mmol/ } \\
\cline { 2 - 10 } & Total VFA & AA & PA & BA & IBA & IVA & VA & AA/PA & pH \\
\hline Treatment & & & & & & & & & \\
Control & $116.9^{\mathrm{a}}$ & $60.1^{\mathrm{a}}$ & $33.2^{\mathrm{a}}$ & $16.6^{\mathrm{a}}$ & $2.56^{\mathrm{a}}$ & 2.23 & $2.16^{\mathrm{a}}$ & $1.81^{\mathrm{a}}$ & 5.88 \\
Oregano & $94.9^{\mathrm{c}}$ & $46.5^{\mathrm{c}}$ & $27.6^{\mathrm{c}}$ & $15.1^{\mathrm{c}}$ & $1.93^{\mathrm{b}}$ & 1.99 & $1.72^{\mathrm{b}}$ & $1.68^{\mathrm{b}}$ & 5.94 \\
Capsicum & $107.1^{\mathrm{b}}$ & $54.4^{\mathrm{b}}$ & $30.4^{\mathrm{b}}$ & $16.0^{\mathrm{a}}$ & $2.07^{\mathrm{b}}$ & 2.07 & $2.04^{\mathrm{a}}$ & $1.79^{\mathrm{a}}$ & 6.01 \\
SE & 0.8 & 0.6 & 0.4 & 0.3 & 0.1 & 0.6 & 0.9 & 0.03 & 0.09 \\
\hline Sex & & & & & & & & & \\
Male & $108.5^{\mathrm{a}}$ & $55.16^{\mathrm{a}}$ & $30.85^{\mathrm{a}}$ & 16.00 & 2.17 & $2.19^{\mathrm{a}}$ & $2.10^{\mathrm{a}}$ & 1.78 & 6.00 \\
Female & $103.9^{\mathrm{b}}$ & $52.11^{\mathrm{b}}$ & $29.98^{\mathrm{b}}$ & 15.70 & 2.21 & $2.00^{\mathrm{b}}$ & $1.85^{\mathrm{b}}$ & 1.74 & 5.88 \\
SE & 0.6 & 0.4 & 0.3 & 0.2 & 0.8 & 0.04 & 0.06 & 0.02 & 0.07 \\
\hline$P$-value & & & & & & & & & \\
Treatment & 0.001 & 0.001 & 0.001 & 0.002 & 0.001 & 0.059 & 0.002 & 0.022 & 0.608 \\
Sex & 0.001 & 0.001 & 0.048 & 0.260 & 0.659 & 0.010 & 0.010 & 0.252 & 0.302 \\
Group x sex & 0.016 & 0.057 & 0.024 & 0.760 & 0.300 & 0.331 & 0.361 & 0.712 & 0.036 \\
\hline
\end{tabular}

VFA: volatile fatty acid, AA: acetate, PA: propionate, BA: butyrate, IBA: isobutyrate, VA: valerate, IVA: isovalerate

a,b,c Main effect means with a common superscript did not differ significantly $(P<0.05)$

Whereas oregano leads in the increasing demand for aromatic plants in the world, chilli pepper extract is preferred because of its unique aroma and secondary metabolites, which are effective in rumen fermentation. In this study, the diets did not detectably affect LW, DWG, DMI and FCR. However, male lambs grew faster than females and were therefore heavier at the end of the study, a finding that was consistent with previous studies (Kashan et al., 2005; Ozdogan et al., 2011; Mohammed et al., 2017). The sexes responded to the dietary supplements in a similar manner. Canbolat et al. (2018) reported that DWG of lambs decreased $(P<0.05)$ linearly with increasing amounts $(0,400,800,1200 \mathrm{mg} / \mathrm{kg} \mathrm{DM})$ of oregano oil in their diets. These effects were coincident with numerically negative changes in LW, DMI and FCR. Chen et al. (2019) found that lambs that consumed 0, 86 and $172 \mathrm{mg} /$ day of a mixture of Capsicum oleoresin and sweetener decreased their DMI linearly $(P=0.06)$ with increasing concentrations of the Capsicum oleoresin and sweetener, although DWG and FCR were not affected.

No differences were seen between the treatments in the constituents of the serum profile (urea, creatine, total protein, albumin, amylase, AST, ALT and GGT). Effects of gender and the interaction of treatment with gender were not detected. Previously, increased levels of dietary oregano oil have resulted in decreased serum glucose, urea, TVFA, and triglyceride levels (Canbolat et al., 2018). However, these effects were consistent across studies because serum cholesterol, triglyceride, high-density lipoprotein, and low-density lipoprotein of lambs were not affected by the addition of 250 and $500 \mathrm{ppm}$ oregano essential oil (Unal \& Kocabagli, 2014). Further, only serum insulin was found to be affected by diets containing 0, 86 and $172 \mathrm{mg} /$ day Capsicum oleoresin and sweetener from among the group of serum constituents that were analysed, including beta-hydroxybutyrate, non-esterified fatty acids, insulin, glucose, and cortisol (Chen et al., 2019).

Additional studies evaluated the changes in rumen function and its microbial population resulting from dietary inclusion of oregano oil and hot pepper extracts (Klevenhusen et al., 2012; Cobellis et al., 2015; Oh et al., 2015; Oh et al., 2016). Secondary effects were said to alter intestinal physiology, increasing mucosal blood flow rate and animal health (Cardozo et al., 2006; Sordillo \& Aitken, 2009; Weiss \& Wardrop, 2010; Holzer, 2011; Hashemzadeh-Cigari et al., 2014; Alford et al., 2016; Adaszek et al., 2019). In the current study, the TVFA, AA, PA, BA, IBA, VA, and the AA/PA values were significantly lower in the rumen of lambs fed diets containing oregano oil or Capsicum oleoresin extract than in the the control group two hours after feeding, with oregano oil having greater effects than Capsicum oleoresin. This result was believed to have been caused by suppression of the microorganism population in the rumen. However, changes in TVFA, AA, $\mathrm{PA}, \mathrm{AA}$ to $\mathrm{PA}$ ratio, and rumen $\mathrm{pH}$, although negative, were not significant in response to supplementation with $12 \%$ or $4.21 \%$ oil from oregano (Oh et al., 2015; Olijhoek et al., 2019). It has been claimed that 
supplying oregano essential oil could enhance the growth of certain rumen microbial populations, but the shifts were influenced by the amount of oil that was provided, with a low amount being favourable for rumen microbial populations, and higher amounts being detrimental to those populations (Zhou et al., 2019). Selenomonas are known to be more sensitive to oregano oil than Streptococcus bovis and thus the lactate produced by $S$. bovis cannot be metabolized rapidly by Selenomonas (Calsamiglia et al., 2007), resulting in an accumulation of lactic acid.

Adding $300 \mathrm{mg}$ oregano oil or Capsicum oleoresin extract to the diet was insufficient to alter the rumen $\mathrm{pH}$ of the lambs in the current study. However, the additions of $300 \mathrm{mg}$ oregano oil and Capsicum oleoresin extract produced a numerically greater rumen $\mathrm{pH}$ than in the control group. Previously, supplementation with oregano oil decreased the $\mathrm{pH}$ of rumen fluid (Castillejos et al., 2008). However, supplementation with 500 $\mathrm{mg} /$ day capsicum extract did not produce detectable effects on rumen $\mathrm{pH}, \mathrm{PA}, \mathrm{AA}$, and $\mathrm{AA}$ to $\mathrm{PA}$ ratio, TVFA, and AA to butyrate ratio (Fandiño et al., 2008).

Female lambs had lower levels of rumen VFAs than male lambs in this study. This might be the result of differences in the rumen microbial populations, because Li et al. (2019) observed that heifers had significantly greater numbers of bacteria and fewer arachea than bulls.

\section{Conclusions}

Diets containing oregano oil or Capsicum oleoresin extract had neglible effects on the fattening performance and serum constituents of weaned lambs. However, total VFA, AA, PA, BA, IBA, IVA, VA and the AA/PA ratio in the rumen were lower at two hours after feeding in control lambs than those supplemented with oregano oil and Capsicum oleoresin extract. Dietary supplementation with oregano oil had a greater effect on the rumen VFA than Capsicum oleoresin extract. Thus, while these additives did not impinge on the fattening performance or serum constituents of the lambs, they had positive effects on rumen physiology.

\section{Acknowledgements}

This study was supported by Ege University Scientific Research Projects Directorate under Grant 2016-ZRF-070.

\section{Authors' Contributions}

HBÜ and HI designed the study. HBÜ and ÇK executed the study. HBÜ, MÖ and ÖC implemented the study and analysed the samples. HBÜ, HI and ÇK drafted the manuscript.

\section{Conflict of Interest Declaration}

There is no conflict of interest.

\section{References}

Adaszek, L., Gadomska, D., Mazurek, L., Łyp P., Madany, J. \& Winiarczyk, S., 2019. Properties of capsaicin and its utility in veterinary and human medicine. Research in Veterinary Science 123, 14-19. https://doi.org/10.1016/j.rvsc.2018.12.002

Alford, J.B., Castro, J.G., Oosthuysen, E.R., Rosasco, S.L., Richins, R.D., Scholljegerdes, E.J., Hallford, D.M. \& Loest, C.A., 2016. Effects of capsaicin source on blood capsaicin, glucose and insulin concentrations, rumen fermentation and nitrogen balance of sheep. Proceedings, Western Section, American Society of Animal Science 67, 171-175. https://doi.org/10.2527/jam2016-1645

AOAC (Association of Official Analytical Chemists), 1997. Official methods of analysis.16th ed, Washington DC, USA.

Babu, P.S. \& Srinivasan, K. 1997. Influence of dietary capsaicin and onion on the metabolic abnormalities associated with streptozotocin induced diabetes mellitus. Molecularand Cellular Biochemistry 175,49-57.

Burt, S., 2004. Essential oils: Their antibacterial properties and potential applications in foods: A review. International Journal of Food Microbiology 94(3), 223-253. https://doi.org/10.1016/j.ijfoodmicro.2004.03.022

Busquet, M., Calsamiglia, S., Ferret, A. \& Kamel, C., 2006. Plant extracts affect in vitro rumen microbial fermentation. Journal of Dairy Science 89,761-771. https://doi.org/10.3168/jds.S0022-0302(06)72137-3

Calsamiglia, S., Busquet, M., Cardozo, P.W., Castillejos, L. \& Ferret, A., 2007. Essential oils as modifiers of rumen microbial fermentation. Journal of Dairy Science 90, 2580-2595. https://doi.org/10.3168/jds.2006-644

Canbolat, O., Filya, I. \& Kamalak, A., 2018. Effect of oregano oil on growth performance, rumen fermentation parameters and blood metabolites of growing lambs. Livestock Research for Rural Development 30(4), http://lrrd.cipav.org.co//rrd30/4/adem30059.html

Cardozo, P.W., Calsamiglia, S., Ferret, A. \& Kamel, C., 2006. Effects of alfalfa extract, anise, capsicum, and a mixture of cinnamaldehyde and eugenol on ruminal fermentation and protein degradation in beef heifers fed a highconcentrate diet. Journal of Animal Science 84, 2801-2808. https://doi.org/10.2527/jas.2005-593

Cardozo, P.W., Calsamiglia, S., Ferret, A. \& Kamel, C., 2005. Screening for the effects of natural plant extracts at different $\mathrm{pH}$ on in vitro rumen microbial fermentation of a high-concentrate diet for beef cattle. Journal of Animal Science 83, 2572-2579. https://doi.org/10.2527/2005.83112572x

Castillejos, L., Calsamiglia, S. \& Ferret, A. 2006. Effect of essential oil active compounds on rumen microbial fermentation and nutrient flow in in vitro systems. Journal of Dairy Science 89, 2649-2658. https://doi.org/10.3168/jds.S0022-0302(06)72341-4 
Castillejos, L., Calsamiglia, S., Martín-Tereso, J. \& Ter Wijlen, H. 2008. In vitro evaluation of effects of ten essential oils at three doses on ruminal fermentation of high concentrate feedlot-type diets. Animal Feed Science and Technology 145, 259-270. https://doi.org/10.1016/j.anifeedsci.2007.05.037

Chaiyasit, K., Khovidhunkit, W. \& Wittayalertpanya, S., 2009. Pharmacokinetic and the effect of capsaicin in Capsicum frutescens on decreasing plasma glucose level. Journal of the Medical Association of Thailand 92, 108-113. http://europepmc.org/article/med/19260251

Chen, X.J., Nedelkov K., Oh J., Harper, M.T., Wall E.H., Felix, T.L. \& Hristov, A.N., 2019. Effect of a blend of artificial sweetener and capsicum on productive performance and blood chemistry in growing lambs. Animal Feed Science and Technology 258, 114308. https://doi.org/10.1016/j.anifeedsci.2019.114308

Cobellis, G., Petrozzi, A., Forte, C., Acuti, G., Orrù, M., Marcotullio, M.C., Aquino, A., Nicolini, A., Mazza, V. \& TrabalzaMarinucci, M., 2015. Evaluation of the effects of mitigation on methane and ammonia production by using Origanum vulgare L. and Rosmarinus officinalis L. essential oils on in vitro rumen fermentation systems. Sustainability 7, 12856-12869. https://doi.org/10.3390/su70912856

Erwin, E.S., Marco, G.J. \& Emery, E.M., 1961. Volatile fatty acid analyses of blood and rumen fluid by gas chromatography. Journal of Dairy Science 44, 1768. https://doi.org/10.3168/jds.S0022-0302(61)89956-6

Fandiño, I., Calsamiglia, S., Ferret, A. \& Blanch, M., 2008. Anise and capsicum as alternatives to monensin to modify rumen fermentation in beef heifers fed a high concentrate diet. Animal Feed Science and Technology 145, 409417. https://doi.org/10.1016/j.anifeedsci.2007.04.018

Foskolos, A., Ferret, A., Siurana, A., Castillejos, L. \& Calsamiglia, S., 2020. Effects of capsicum and propyl-propane thiosulfonate on rumen fermentation, digestion, and milk production and composition in dairy cows. Animals 10(859), 1-14. https://doi.org/10.3390/ani10050859

Hashemzadeh-Cigari, F., Khorvash, M., Ghorbani, G.R., Kadivar, M., Riasi, A. \& Zebeli, Q., 2014. Effects of supplementation with a phytobiotics-rich herbal mixture on performance, udder health, and metabolic status of Holstein cows with various levels of milk somatic cell counts. Journal of Dairy Science 97, 7487-7497. https://doi.org/10.3168/jds.2014-7989

Holzer, P., 2011. Transient receptor potential (TRP) channels as drug targets for diseases of the digestive system. Pharmacol. Ther. 131, 142-170. https://doi.org/10.1016/j.pharmthera.2011.03.006

Kashan, N.E.J., Manafi Azar, G.H., Afzalzadeh, A. \& Salehi, S., 2005. Growth performance and carcass quality of fattening lambs from fat-tailed and tailed sheep breeds. Small Ruminant Research 60, $267-271$. https://doi.org/10.1016/j.smallrumres.2005.01.001

Klevenhusen, F., Muro-Reyes, A., Khiaosa-ard, R., Metzler-Zebeli, B.U. \& Zebeli, Q., 2012. A meta-analysis of effects of chemical composition of incubated diet and bioactive compounds on in vitro ruminal fermentation. Anim. Feed Sci. Technol. 176, 61-69. https://doi.org/10.1016/j.anifeedsci.2012.07.008

Koffi-Nevry, R., Kouassi, K.C., Nanga, Z.Y., Koussémon M. \& Loukou, G.Y., 2012. Antibacterial activity of two bell pepper extracts: Capsicum annuum L. and Capsicum frutescens. International Journal of Food Properties 15, 961-971.

Li, F., Li, C., Chen, Y., Liu, J., Zhang, C., Irving, B., Fitzsimmons, C., Plastow, G. \& Guan, L.L., 2019. Host genetics influence the rumen microbiota and heritable rumen microbial features associate with feed efficiency in cattle. Microbiome 7(1), 92. DOI: 10.1186/s40168-019-0699-1

Maksimova, V., Koleva, G.L., Ruskovska, T., Cetanovska, A., Gulaboski, R., 2014. Antioxidative effect of Capsicum oleoresins compared with pure capsaicin. IOSR Journal of Pharmacy 4(11), 44-48. https://doi.org/10.9790/301304011044048

McGuffey, R.K., Richardson, L.F. \& Wilkinson, J.I.D., 2001. lonophore for dairy cattle: Current status and future outlook. J. Dairy Sci. 84, 194-203. https://doi.org/10.3168/jds.S0022-0302(01)70218-4

Mohammed, S.F., Al-Gburi, O.S.H. \& Abbas, E.R., 2017. Effect of Coriandrum sativum on live weight gain, lipids, hematological and some blood parameters of Awassi female and male lambs. Advances in Environmental Biology, 11(4), 19-23.

https://go.gale.com/ps/anonymous?id=GALE\%7CA499696204\&sid=googleScholar\&v=2.1\&it=r\&linkaccess=abs\&i $s s n=19950756 \& p=A O N E \& s w=w$

NRC., 1985. Nutrient requirements of sheep. Sixth revised edition, National Research Council. National Academy Press, Washington DC, USA.

Oh, J., Bravo, D.M., Wall, E.H. \& Hristov, A.N., 2016. Rumen disappearance of capsaicin and dihydrocapsaicin in lactating dairy cows. J. Anim. Sci 94, E-Suppl. 5. Erişim. http://dx.doi.org/10.2527/jam2016-1644

Oh, J., Giallongo, F., Frederick, T., Pate, J., Walusimbi, S., Elias, R.J., Wall, E.H., Bravo, D. \& Hristov, A.N. 2015. Effects of dietary Capsicum oleoresin on productivity and immune responses in lactating dairy cows. Journal of Dairy Science 98, 6327-6339. https://doi.org/10.3168/jds.2014-9294

Oh, J. Harper, M., Giallongo, F., Bravo, D.M., Wall, E.H. \& Hristov, A.N., 2017. Effects of rumen-protected Capsicum oleoresin on productivity and responses to a glucose tolerance test in lactating dairy cows. Journal of Dairy Science 100, 1888-1901. https://doi.org/10.3168/jds.2016-11665

Olijhoek, DW., Hellwing, ALF., Grevsen, K., Haveman, LS., Chowdhury, MR., Løvendahl, P., Weisbjerg, MR., Noel, SJ., Højberg, O., Wiking, L. \& Lund, P., 2019. Effect of dried oregano (Origanum vulgare L.) plant material in feed on methane production, rumen fermentation, nutrient digestibility, and milk fatty acid composition in dairy cows. Journal of Dairy Science 102, 9902-9918. https://doi.org/10.3168/jds.2019-16329

Ozdogan, M., Onenc, S.S. \& Onenc, A., 2011. Fattening performance, blood parameters and slaughter traits of Karya lambs consuming blend of essential oil compounds. African Journal of Biotechnology 10(34), 6663-6669. https://www.ajol.info/index.php/ajb/article/view/94660 
Reyes-Escogido, M.L., Gonzalez-Mondragon, E.G. \& Vazquez-Tzompantzi, E., 2011. Chemical and pharmacological aspects of capsaicin. Molecules 16, 1253-1270. https://doi.org/10.3390/molecules 16021253

Rodríguez-Prado, M., Ferret, A., Zwieten, J., Gonzalez, L., Bravo, D. \& Calsamiglia, S., 2012. Effects of dietary addition of capsicum extract on intake, water consumption, and rumen fermentation of fattening heifers fed a highconcentrate diet. J. Anim. Sci. 90, 1-6. DOI:10.2527/jas2010-3191

Sanati, S., Razavi, B.M. \& Hosseinzadeh, H., 2018. A review of the effects of Capsicum annuum L. and its constituent, capsaicin, in metabolic syndrome. Iran J. Basic Med. Sci. 21, 439-448. https://doi.org/10.22038/IJBMS.2018.25200.6238

Seirafy, H. \& Sobhanirad, S., 2017. Effects of oregano (Origanum vulgare) and thyme (Thymus vulgaris) oils on growth performance and blood parameters in Holstein suckling calves. Iranian Journal of Applied Animal Science 7(4), 585-593 http://ijas.iaurasht.ac.ir/article_535733.html

Sordillo, L. M. \& Aitken, S.L., 2009. Impact of oxidative stress on the health and immune function of dairy cattle. Vet. Immunol. Immunopathol. 128, 104-109. https://doi.org/10.1016/j.vetimm.2008.10.305

TSI, 1991. Animal feeds determination of metabolizable energy (chemical method). Turkish Standards Institute. Publication No, 9610.

Unal, A. \& Kocabagli, N., 2014. Effect of different dosages of oregano oil on performance and some blood parameters in lambs. Veterinarian Faculty Journal of Ankara Universlty 61, 199-204. http://dergiler.ankara.edu.tr/dergiler/11/1893/19852.pdf

Van Soest, P.J., Robertson, J.B. \& Lewis, B.A., 1991. Methods for dietary fibre, neutral detergent fibre, and nonstarch polysaccharides in relation to animal nutrition. Journal of Dairy Science 74, 3583-3597. https://doi.org/10.3168/jds.S0022-0302(91)78551-2

Veldhuizen, E.J.A, Bokhoven, J.L.M.T., Zweijtzer, C., Burt, S.A. \& Haagsman, H.P., 2006. Structural requirements for the antimicrobial activity of carvacrol. J. Agric. Food Chem. 54, 1874-1879. https://doi.org/10.1021/jf052564y

Weiss, D.J. \& Wardrop, K.J., 2010. Schalm's veterinary hematology. 6th ed. Blackwell, Ames, IA. https://books.google.com.tr/books/about/Schalm_s_Veterinary_Hematology.html?id=|QXtQn593F4C\&redir_esc=y

Zhou, R., Wu, J., Zhang, L., Liu, L., Casper, D.P., Jiao, T., Liu, T. Wang, J., Lang, X., Song, S. \& Gong, X., 2019. Effects of oregano essential oil on the ruminal $\mathrm{pH}$ and microbial population of sheep. PLoS ONE 14(5), e0217054. https://doi.org/10.1371/journal.pone.0217054 